\title{
O MODELO DE DESJUDICIALIZAÇÃO COLABORATIVA DA EXECUÇÃO CIVIL PORTUGUESA: UMA ABORDAGEM A PARTIR DOS SEUS PROCEDIMENTOS E SUA APLICABILIDADE AO BRASIL
}

\author{
THE COLLABORATIVE DISJUDICIALIZATION MODEL OF PORTUGUESE CIVIL \\ EXECUTION: AN APPROACH FROM ITS PROCEDURES AND ITS APPLICABILITY TO \\ BRAZIL
}

\section{Roberto Correia da Silva Gomes Caldas}

\begin{abstract}
Mestre e Doutor em Direito do Estado pela PUC/SP - Pontifícia Universidade Católica de São Paulo. Professor em Direito da PUC/SP - Pontifícia Universidade Católica de São Paulo. Professor permanente do Curso de Mestrado do PPGD da FMU e de Maestría en Derecho de las RRII y de la Integración en América Latina de la UDE Universidad de la Empresa - Montevidéu/Uruguai. External Researcher da Cátedra Jean Monnet em Direito da UFMG - Universidade Federal de Minas Gerais. Coordenador da Rede de Pesquisa "Integração, Estado e Governança”. Advogado no Brasil e em Portugal. E-mail: robertocsgcaldas@uol.com.br
\end{abstract}

\begin{abstract}
Alexandre Augusto Fernandes Meira
Mestre em Direito e Doutorando em Educação pela UNINOVE - Universidade Nove de Julho. Especialista em Direito Público, Direito Administrativo (2015) e Direito Constitucional (2016), pela UNIFIA/SP - Centro Universitário Amparense. Bacharel em Direito pela Universidade Presbiteriana Mackenzie (2003) e em Administração de Empresas pela Fundação Armando Alvares Penteado - FAAP (1994). Bolsista pesquisador CAPES. E-mail: alemgaya@hotmail.com
\end{abstract}

Recebido em: 27/06/2019

Aprovado em: 14/04/2020

RESUMO: Este trabalho tem por objetivo analisar as relativamente recentes reformas do processo executivo português, de modo a se extrair seu modelo de desjudicialização colaborativa tal qual consubstanciado pelas reformas legislativas de 2003 e 2008, bem como pelo Código de Processo Civil de 2013, à luz das experiências de outros Estados europeus, caracterizando uma hodierna quebra de monopólio quanto às atividades judiciárias até então conduzidas por parte do Estadojuiz. Dada esta circunstância, a abordagem empreendida foca no papel que passa a ser desempenhado pelo agente de execução, em uma necessária quadrilarização (e não mais uma triangularização) da relação jurídica para a deflagração do novel processo de execução lusitano, o que, no estudo em questão, é tomado como objeto de análise comparativa com a realidade pátria, de modo a se poder adotar de lege ferenda, ainda que em parte, algumas das medidas lá adotadas para se galgar, aqui, maiores celeridade, eficiência e efetividade processuais e procedimentais para a satisfação dos créditos em pretensão judicialmente deduzida. Assim, este trabalho dá notícias, ao final, da pioneira experiência desjudicializante pátria, fomentada por incentivo do CNJ - Conselho Nacional de Justiça no âmbito da Justiça do Trabalho em seu respectivo processo de execução para satisfação dos créditos laborais, concluindo-se, na sequência, pela possibilidade de que certas atividades colaborativas de excussão atribuídas ao agente de execução português possam ser 
também transferidas ao oficial de justiça brasileiro.

Palavras-chave: Desjudicialização colaborativa; agente de execução; atividade judiciária eficiente; efetividade jurisdicional; celeridade processual.

\begin{abstract}
This paper aims to analyze the relatively recent reforms of the Portuguese executive process, in order to extract its model of collaborative disjudicialization as embodied by the legislative reforms of 2003 and 2008, as well as by the Civil Procedure Code of 2013, in the light of the experiences of other European States, characterizing a current breach of monopoly regarding the judiciary activities thitherto conducted by the Judge State. Given this circumstance, the approach undertaken focuses on the role that is played by the execution agent in a necessary quadrilization (and no longer a triangularization) of the legal relationship for the outbreak of the novel lusitanian excussion process, which, in the study in question, is taken as the object of comparative analysis with the reality of the our country, in order to be able to adopt lege ferenda, although in part, some of the measures there adopted to achieve here greater procedural and processual celerity, efficiency and effectivity in order to satisfy the credits in court deducted. Thus, in the end, this work gives a report on the pioneering disjudicializating experience of the our country, promoted by the CNJ - Conselho Nacional de Justiça, in the scope of the Labor Court in its respective process of execution for the satisfaction of the labor credits, concluding, in the sequence, that certain collaborative activities of excussion attributed to the portuguese execution agent may also be transferred to the brazilian judicial officer.
\end{abstract}

Keywords: Collaborative disjudicialization; execution agent; efficient judiciary activity; jurisdictional effectivity; processual celerity.

SUMÁRIO: Introdução. 1. Práticas colaborativas no processo civil: uma nova óptica procedimental desjudicializante. 2. A reforma da execução civil em Portugal. 3. O procedimento executivo lusitano: noções gerais. 3.1. Ritos ordinário e sumário: o papel do agente de execução. 4. A experiência brasileira desjudicializante executiva civil: o exemplo da Justiça do Trabalho. Conclusão. Referências.

\title{
INTRODUÇÃO
}

Tendo em consideração que a função precípua da Justiça deve ser a adequada, correta e concreta solução dos litígios, principalmente à luz dos primados da celeridade e razoável duração do processo, subsistiam evidentes problemas sociais, no Estado português, de uma impossibilidade efetiva, em tempo hábil, de se cobrarem as dívidas já vencidas, o que passou a ser enfrentado, de forma mais rigorosa, a partir das reformas legislativas de 2003 e 2008 que introduziram um modelo desjudicializado e colaborativo na execução civil portuguesa, caracterizado pela quebra do monopólio das atividades judiciárias de condução e direção do processo por parte do Estado-juiz atividades judiciárias não-jurisdicionais, segundo Ribeiro $(1991)^{1}$-, paradigma o qual restou mantido pelo ulterior Código de Processo Civil de 2013.

\footnotetext{
${ }^{1}$ Segundo a classificação de Ribeiro (1991) que ora se adota para os atos emanados do Poder Judiciário, tem-se sua divisão em atos judiciários (decorrentes da atividade judiciária) como gênero, dos quais os atos jurisdicionais, também ditos judiciários em sentido estrito (havidos em consequência de atividade jurisdicional, ou seja, de composição dos litígios em nome do Estado), consubstanciam espécie que se configura em paralelo a outra, existente em razão do exercício de outras funções, mediante atividades judiciárias não-jurisdicionais, as quais são diversificadas, incluindo atos de jurisdição voluntária, bem como, no caso do Brasil, de autogoverno do Poder Judiciário (e não apenas da magistratura), de cunho legislativo e, ainda, censórios e disciplinares (correicionais), normativos (regulamentares),
}

Revista de Direito Brasileira | Florianólopis, SC | v. 25 | n. 10 | p. 345-365 | Jan./Abr. 2020 
Com efeito, conhece-se, sob um ponto de vista de crescimento da economia nacional dos Estados, quão nefastos são os efeitos desestimulantes decorrentes das dificuldades ou da demora para o percebimento judicial de créditos por parte dos respectivos agentes econômicos, implicando, quase que inevitavelmente, desaceleração ou estagnação do referido crescimento e, em consequência, risco financeiro para as empresas com, deste modo, aumento do número de desemprego e da informalidade de mercado.

Tais efeitos negativos, hoje, são inclusive considerados como frutos colaterais, no caso de Portugal, da sua adesão à política globalizante e neoliberal, nomeadamente no que concerne aos investimentos internos e exteriores, como também ao aumento do poder aquisitivo com incentivo ao consumo, sem que, para tanto, houvessem sido previamente implementados mecanismos capazes de tornar o Judiciário português preparado para tal empreitada.

Em verdade, dentro do contemporâneo contexto regional de crise da União Europeia, economias que apresentem níveis significativos de inadimplência, maxime ante a expressiva massificação do consumo por meio de incentivos estatais e regionais, acabam por gerar um elevado aumento de ações executivas por pequenas dívidas, em indesejada sobrecarga do Poder Judiciário de certos Estados-membros que, a seu turno, acarreta dificuldades ou impossibilidades de uma efetiva e célere satisfação de direitos creditícios, a impor-se, em subsequência, como um fator de desinteresse por parte de investidores, como ocorrido em Portugal.

Acima de tudo, a recente realidade portuguesa expressava um tradicional quadro institucional de ineficiente e inefetivo funcionamento do sistema judicial (tal qual acontecia em parte significativa dos Estados-membros da União Europeia), habitualmente moroso consoante observado antes das reformas de 2003 e 2008 no instituto da execução civil, alterações legislativas estas que em sua essência, conforme dito, restaram resguardadas pelo Código de Processo Civil de 2013.

É a partir das referidas reformas nos procedimentos de excussão que se tem o surgimento da novel figura de um operador privado (o agente de execução ${ }^{2}$ ), o qual passa a ser visto como a via pela qual se deveria buscar um resultado que pudesse reverter as implicações verificadas quanto ao descrédito público sobre a capacidade do Estado lusitano em promover uma prestação jurisdicional não apenas eficiente, mas efetiva e célere, sendo que tal descrédito se notava alimentado pela desconfiança generalizada dos cidadãos europeus e operadores econômicos no sistema judicial português.

Ante tal circunstância, evidenciam-se nesse quadro os motivos para as reformas da ação executiva no processo civil lusitano, quais sejam, adequar Portugal às diretrizes da União Europeia, tornar o processo executivo mais célere e efetivo mediante uma duração razoável, bem como combater a morosidade da melhor forma e com o menor custo possível, e, deste modo, com a maior eficiência segundo critérios objetivos de uma otimicidade paretiana almejada.

Assim, no estudo aqui empreendido serão apresentadas razões de distintos matizes que se verificam presentes na gênese das reformas ocorridas em 2003 e 2008, designadamente vinculadas à criação de novos paradigmas processuais alicerçados em uma visão de ruptura com a forma de tramitação anterior e tradicional, mediante a introdução de práticas judiciárias procedimentais colaborativas (também ditas cooperativas), por intermédio de um profissional liberal, com sujeições e prerrogativas de ordem pública (funções públicas), a quem fora autorizada a realização de atos de condução e direção processual, como também o cumprimento de determinações advindas do juiz de execução.

administrativos em sentido estrito (nomeação, demissão e promoção de servidores públicos, realização de licitações públicas etc.) e demais de natureza anômala.

${ }^{2} \mathrm{O}$ agente de execução português tem sua inspiração a partir dos Huissiers de Justice do Direito francês, também existentes na Bélgica, Holanda, Luxemburgo e Grécia, entre outros Estados europeus, como, outrossim, no Sheriff Officer, havido na Escócia. Na Alemanha e na Áustria há, ainda, a figura do agente de execução (Gerichtsvollzieher), malgrado, no caso, seja um agente público da Justiça, remunerado pelos cofres públicos.

Revista de Direito Brasileira | Florianólopis, SC | v. 25 | n. 10 | p. 345-365 | Jan./Abr. 2020 
De conseguinte, em função da mudança do paradigma jurídico das ações executivas no Direito Processual Civil português, neste aspecto distanciando-se de suas raízes romanogermânicas, implementou-se a ideia reformadora colaborativa de atribuição das atividades judiciais (ou judiciárias) procedimentais e, por isso, não jurisdicionais, para se proporcionar a pretendida maior celeridade de tramitação.

A continuidade da implantação de tal tendência procedimental cooperativa introduzida pelas reformas de 2003 e 2008, há que se mencionar, trouxe a necessidade de se coadunar não só a, por isso, renovada e reinterpretada figura (haurida do Direito Administrativo) do particular em colaboração à Administração Pública (enquanto agente no exercício de munus público - vide a respeito: Mello, 2019) com a processualística tradicional, mas também com o advento do novo Código de Processo Civil português de 2013, porquanto, tendo este mantido intacta a essência estrutural das reformas supracitadas quanto às ações de execução, acabou por permitir o convívio destas com as hodiernas medidas de aperfeiçoamento processual que encerra, em evidente busca da efetivação do direito fundamental do acesso à justiça e concretização das tutelas jurisdicionais executórias.

O fenômeno desjudicializante cooperativo, não obstante, traz questionamentos quanto aos limites e à possibilidade de transferência a particulares de competências estatais, com seu inerente jus imperii; a respeito das atividades judiciárias procedimentais e sua atribuição a um terceiro particular em viabilização a uma efetiva dicção do Direito por parte do Estado-juiz, o qual, assim, passa apenas a fiscalizar esta atuação (no caso, dos agentes de execução) ficando com mais tempo para se ater às atividades jurisdicionais típicas e exclusivas da magistratura, embora não seja da tradição de ordenamentos jurídicos como, e. g., o brasileiro e o português, é medida que, ressalvados pontos de dissonância, tem sido implementada e aceita pela doutrina europeia atual, consoante relata Farias (2015).

Tal situação, vale frisar, não implica atribuição de jurisdictio a particulares - vez que o Estado-juiz permanece como titular exclusivo de tal mister (de prolação da tutela jurisdicional executiva para solução dos conflitos creditícios) -, mas de competências próprias às sujeições e prerrogativas judiciárias procedimentais (inclusive de direção processual), havendo, de conseguinte, a transferência, segundo disposições legais expressas, de atribuições administrativoprocedimentais mediante fiscalização estatal (in casu, repita-se, por parte do Estado-juiz, o juiz de execução).

Com as reformas, como se verá adiante, os atos judiciários procedimentais são demandados do Poder Judiciário para que, simplesmente, o agente de execução possa exercer tal atividade administrativa, ou por atribuições próprias, ou executando atos emanados do juiz de execução (o principal sujeito do processo), livrando-o para deter-se, precipuamente, à atividade jurisdicional para resolução dos conflitos de acordo com o modelo de desjudicialização da execução civil estabelecida no Direito Processual português.

À luz dessa realidade fático-jurídica ora trazida, e mediante o corte metodológico utilizado no estudo aqui desenvolvido, na sequência passa-se a expor a nova óptica procedimental desjudicializante e as práticas colaborativas que com ela são adotadas no processo civil, observando-se, em seguida, a tessitura que envolveu a reforma da execução civil em Portugal, bem como as implicações no cotidiano de sua aplicação, com a verificação, na subsequência, da repartição das competências aos envolvidos, quais sejam, os agentes de execução, a Comissão para Acompanhamento dos Auxiliares da Justiça e os juízes de execução, de sorte a extraírem-se conclusões genericamente replicáveis à análise de ordenamentos jurídicos similares, como o brasileiro $^{3}$, na busca de soluções para problemas congêneres.

Na parte derradeira do estudo, far-se-á uma análise dos ritos procedimentais para a execução por quantia, quais sejam, ordinário e sumário, sendo este último utilizado em situações

\footnotetext{
${ }^{3}$ Para uma análise a respeito dos efeitos da Reforma do Poder Judiciário brasileiro e a mudança de paradigma que estabelece, recomenda-se a crítica de: Rosa (2012); e Campos, Meyer-Pflug (2013).
}

Revista de Direito Brasileira | Florianólopis, SC | v. 25 | n. 10 | p. 345-365 | Jan./Abr. 2020 
excepcionais, nas execuções de obrigações certas, líquidas e exigíveis fundadas em decisão arbitral, títulos extrajudiciais de baixo valor e de obrigações pecuniárias garantidas por penhor ou hipoteca, bem como decisões judiciais que não devam ser executadas nos próprios autos do processo de conhecimento.

Ao final, este trabalho dá notícias sobre a pioneira experiência desjudicializante pátria, fomentada por incentivo do CNJ - Conselho Nacional de Justiça no âmbito da Justiça do Trabalho em seu respectivo processo de execução para satisfação dos créditos laborais, concluindo-se, na sequência, pela possibilidade de que certas atividades colaborativas de excussão atribuídas aos agentes de execução portugueses possam ser também transferidas ao oficial de justiça brasileiro.

A metodologia de trabalho, assim, centra-se nos aspectos principais estabelecidos para uma pesquisa baseada na interdisciplinaridade comparativa do tema ao envolver discussões de Direito Administrativo e Processual Civil no que tange à possibilidade e aos limites de atribuição da própria atividade judiciária procedimental a particulares no processo de execução civil (agentes de execução, em Portugal), ou mesmo agentes públicos distintos (oficiais de justiça, no Brasil), de modo a galgarem-se, com isso, maiores celeridade e eficiência na gestão da justiça em prossecução de uma integral efetividade da prestação jurisdicional por parte do Estado-juiz nas execuções patrimoniais civis promovidas em diferentes áreas do Direito (como o Trabalhista, no caso brasileiro enfocado).

Desse modo, o estudo deve se utilizar de método(s) que permita(m) avaliar como, e em que medida, a aplicação de uma nova regulação emparceirada dos atos judiciários procedimentais pode viabilizar um plano de ação que torne o processo de execução civil, à luz do ordenamento jurídico português - e, quiçá, adotando-se em território nacional algumas medidas similares, brasileiro -, mais célere e com maior eficiência na concreção da tutela jurisdicional para satisfação dos créditos inadimplidos, sem prejuízo, é evidente, da imperiosa segurança jurídica quanto aos direitos de ampla defesa e contraditório do executado.

Será propósito deste trabalho, portanto, uma análise avaliativa das recentes reformas executivas civis portuguesas, com vistas à eventual possibilidade, ainda que em parte, de sua aplicação em outros ordenamentos jurídicos similares, maxime à luz da experiência desjudicializante por lá já vivenciada para se implementar maiores celeridade, eficiência e efetividade quanto à satisfação dos créditos pretendidos em juízo, valendo-se, para tanto, do método dutivo, segundo a técnica de abordagem bibliográfica, para construir conceitos que possam produzir uma reflexão crítica a respeito da problemática sob um enfoque jurídico, tanto em esfera global como também em Estados que adotem sistema jurídico de raízes romano-germânicas, como é o caso do Brasil.

\section{PRÁTICAS COLABORATIVAS NO PROCESSO CIVIL: UMA NOVA ÓPTICA PROCEDIMENTAL DESJUDICIALIZANTE}

De acordo com Pedroso (2003), a desjudicialização é apenas uma das facetas imbricadas de um complexo processo social mais amplo, o processo de desregulação social, que pode ocorrer em sentido amplo ou sob a forma de desjuridificação; esta, a sua vez, subdivide-se em deslegalização, informalização da justiça e desjudicialização, o que, para o contexto deste estudo, pode ser entendido enquanto uma desregulamentação estatal de atividades judiciárias nãojurisdicionais de cunho administrativo.

Segundo os ensinamentos de Campilongo (1994), a tríade desformalização, deslegalização e desregulamentação caracteriza o Estado dito neoliberal, ao evidenciar uma redução da sua intervenção direta em certas questões econômico-sociais, principalmente à luz dos chamados constitucionalismo (Moreira Neto, 2003) e administrativismo de resultado (Aragão, 2004), nos quais várias expectativas materiais transformaram-se em autênticas pretensões jurídicas deduzidas pela sociedade. 
Consoante elucidado, com as reformas legislativas processuais lusitanas de 2003 e 2008, ulteriormente mantidas em sua essência pelo Código de Processo Civil português de 2013, instituiu-se um modelo desjudicializado e colaborativo na execução civil, vale salientar, em rompimento com a tradição processualística romano-germânica para, tomando por base experiências de outros Estados europeus, introduzir-se uma quebra do monopólio das atividades judiciárias procedimentais por parte do Estado-juiz, subtraindo-lhe o exercício de atos burocráticos no desenvolvimento da execução civil, os quais, por sua vez, foram distribuídos ao agente de execução, o que originou uma mudança substancial na busca de um processo mais simples (menos regulamentado), ágil (célere e de razoável duração), eficiente e efetivo.

Por isso, as questões enfrentadas por este sistema desjudicializado e colaborativo da execução civil portuguesa, em sua busca de tornar verdadeira e efetiva a tutela jurisdicional em tempo minimamente razoável, inclusive dentro de uma simplificação e agilização dos ritos procedimentais existentes, revelam a transição, a passagem de um processo judicial totalmente estatizado e monopolizado por parte do Estado-juiz, para uma nova concepção processual que incorpora nas práticas judiciárias procedimentais a chamada gestão pública emparceirada, segundo a qual o particular é chamado a colaborar, em exercício de munus público (a exemplo do que ocorre com os advogados), para se ter uma prestação jurisdicional mais célere, eficiente e efetiva, sem se descurar da segurança jurídica segundo um ótimo paretiano objetivamente estabelecido.

Conforme noticiado por Pedroso et al. (2001), já a partir das décadas de 1960 e 1970 há reflexões norte-americanas advindas do modelo anglo-saxão contra o monopólio de parcela das atividades judiciárias do Estado-juiz, de sorte a buscar-se a informalidade e a descentralização dos procedimentos, em fomento à participação ativa dos cidadãos na resolução dos conflitos, mediante a retomada de técnicas preexistentes e abandonadas após a monopolização da jurisdição pelo Estado contemporâneo, não obstante devidamente adaptadas para as necessidades hodiernas, ou seja, segundo novas utilidades e práticas para procedimentos antigos.

De fato, Mitidiero (2011) leciona existirem três modelos processuais, estipulados segundo uma divisão dos trabalhos a serem desempenhados pelas partes que os integram, os quais, a seu turno, são alicerçados em fatores sociais, éticos e lógicos. Classificam-se, assim, em processo isonômico, assimétrico e cooperativo (colaborativo). Quanto a este último, tem-se a demonstração de uma coordenação entre indivíduo, sociedade e Estado, visando fomentar-se uma preocupação nos atores processuais que estabeleça um diálogo entre partes e Estado-juiz, de sorte a desviar-se de confrontos e interações com acirramento de ânimos e antagonismos de posturas.

Vale salientar que, no contexto processual geral contemporâneo, as práticas colaborativas se põem lado a lado aos demais métodos consensuais de resolução de conflitos, notadamente, transação, conciliação e mediação, embora deles se diferenciem, porquanto aplicadas na concomitância da novel compreensão do formalismo-valorativo processual, qual seja, na busca de um equilíbrio entre realização da justiça material e paz social, de um lado, e, de outro, celeridade, eficiência, efetividade, segurança e organização interna justa na condução e direção do próprio processo (gestão processual) (Oliveira, 2009).

É de se ressaltar que a nova óptica procedimental desjudicializante do processo de execução civil português se dá no âmago das relações organizacionais cooperativas de gestão das formas de jurisdição, ou, mais precisamente, no seio das atividades judiciárias, as quais são de cunho administrativo-procedimentais e alheias ao poder jurisdicional (porquanto inerente à atividade judicante exclusiva do Estado-juiz), dizendo respeito, de conseguinte, aos atos ordenatórios atribuídos ao gente de execução, voltados que são para um célere e eficiente andamento processual de excussão colimando sua concreção e, assim, o adimplemento dos créditos pretendidos.

Diante de tal compostura, é evidente a interconexão entre a novel relação jurídicoadministrativa, de cunho colaborativo, dialógico, isto é, concertado - relação esta, no caso em tela, devidamente enfeixada na figura do agente de execução -, e o procedimento de excussão judicial, a estabelecer uma hodierna e inovadora dinâmica de gestão processual, claramente cooperativa, a 
prol de maiores celeridade, eficiência e efetividade. Com efeito, a respeito do contemporâneo significado da referida relação jurídico-administrativa, Moncada esclarece

A perspectiva «relacional» do contacto entre a Administração e os cidadãos compreende diversos fenómenos permanentes que se manifestam de diferentes maneiras mas que se enquadram numa estrutura geral. A estrutura do contacto actual entre a Administração e os cidadãos é decisivamente marcada pela ideia da participação com reflexos no âmbito procedimental e processual e exigindo até uma nova orgânica apta a dar-lhe vazão, de que se tratará posteriormente. Como é sabido, no Estado Social intervencionista generalizaram-se formas de participação na formação da decisão administrativa e de colaboração variada entre os cidadãos e o poder que ficaram conhecidas por concertação e que modificaram necessariamente a orgânica adrninistrativa... (2009, p. 143).

E segue o autor afirmando

(...) certamente que a participação e a concertação facilitam em muito o contacto bilateral entre a Administração e a cidadãos, embora desta realidade não devam ser retiradas consequências apressadas... Pelo que toca à concertação, dita económica e social, as coisas não são diferentes. Trata-se de um fenómeno muito amplo, cujas manifestações não podem ser aqui completamente esclarecidas. A concertação ou consensualidade é uma alternativa à tradicional unilateralidade da decisão e actuação administrativas. Nesta medida, manifesta também o fenómeno da participação administrativa e a presença do interesse privado na formação da mesma decisão, repudiando as concepções, tão apreciadas no nosso país, para as quais o interesse público se opõe necessariamente ao privado e é exclusivo da Administração, o que tem consequências dogmáticas vastíssimas no direito administrativo, mas que não podem ser agora e aqui tratadas... Releva de uma metodologia democrática de obtenção da decisão administrativa muito embora por seu intermédio também não se verifique uma autêntica repartição do poder de decidir pois que o nível respectivo se fica sempre pela fase preparatória da mesma decisão, sem retirar à Administração os seus poderes unilaterais de decisão (MONCADA, 2009, p. 143-145).

Nesse diapasão, é de se esclarecer no caso português ora enfocado, o jus imperii não foi subtraído do Estado-juiz, ao qual ainda é dado a fiscalização e revisão de todos os atos processuais e procedimentais, exercendo evidente e imprescindível atividade correicional, de tutela, podendoo fazer inclusive ex officio na qualidade de corregedor permanente do juízo, segundo entendimento que ora se adota, embora de forma parcimoniosa e emparceirada com a CAAJ - Comissão para o Acompanhamento dos Auxiliares de Justiça e a OSAE - Ordem dos Solicitadores e dos Agentes de Execução, entidades precípua e legalmente estabelecidas para o controle direto (conforme um modelo de intervenção judicial mínimo) das atividades dos agentes de execução.

\section{A REFORMA DA EXECUÇÃO CIVIL EM PORTUGAL}

Até o ano de 2003, Portugal tinha um sistema processual com concentração das atividades procedimentais de execução de títulos enfeixadas no Judiciário, mais especificamente nas mãos do Estado-juiz, controlador e gestor do processo, o qual promovia, dirigia e administrava as diligências necessárias para sua boa tramitação.

Contudo, um cenário de excessivo congestionamento e morosidade de processos, em muito influenciado pelas cobranças de dívidas decorrentes dos percalços econômicos pelos quais o Estado 
lusitano vinha passando, conduziu a uma série de demandas de baixa complexidade e valores, as quais, em agravamento do quadro, tomavam demasiado tempo e recursos dos tribunais portugueses.

Aliado, outrossim, à mencionada tendência de harmonização de sistemas jurídicos na União Europeia, por conta do processo integracionista, tal contexto impulsionou um movimento político de redução da presença do Estado no meio judiciário, o que se deu por intermédio da transferência de certas funções à iniciativa privada, mais especificamente à figura dos agentes de execução.

Tal tendência, diga-se de passagem, já não era inédita no histórico de reformas portuguesas, as quais, em que pese não terem sido até então estendidas ao processo de execução civil, consubstanciavam-se nos “...procedimentos que, antes desta opção legislativa ter tido lugar, já visavam compor situações que não se configuravam como verdadeiros litígios, ..." (Farias, 2015, p. 72).

Nesse diapasão, um grande passo fora dado com a edição do Decreto-lei $n^{\circ}$ 38/2003 que, ante seu objetivo de proporcionar maior eficiência e concreta salvaguarda dos direitos creditícios em Portugal, trouxe uma primeira tentativa de se instituir celeridade, razoável duração e efetividade na tramitação das excussões advindas do aumento de litigiosidade nas últimas décadas.

E tal desiderato se deu permitindo maior atenção por parte do Estado-juiz ao julgamento das lides, cuja pendência implicava um significativo gargalo na fase de execução, mediante o acolhimento de algumas ideias de desjudicialização em voga na Europa.

Este modelo cooperativo de execução, de fato, prima por transferir várias funções para os agentes de execução, sem, contudo, instituir a quebra da reserva jurisdicional e do controle judicial, ou seja, com o Estado-juiz estando a todo momento gozando das sujeições e prerrogativas inerentes à fiscalização e ao controle da gestão das atividades judiciárias (de cunho administrativo) de que apenas fora liberado para centrar-se naquelas voltadas à jurisdição propriamente dita.

Porém, conforme asseverado por Sousa, esta primeira reforma, com suas significativas e relevantes alterações em comparação ao modelo tradicional há muito então vigente, acabou por entrar em vigor “...sem que o terreno estivesse inteiramente preparado para a receber” (2008, p. 207), o que implica afirmar que não havia ainda uma preparação necessária para que tais medidas reformadoras pudessem ser absorvidas pela cultura processual portuguesa em um espaço tão curto de tempo.

Os problemas foram vários, ou seja, desde a falta de recursos humanos e materiais, até os deficitários treinamento e qualificação dos profissionais que viriam a figurar como agentes de execução, bem como a cobrança de honorários considerados elevados e incompatíveis com os valores das excussões de pequenas montas, passando, por outro lado, pela previsão de diligências em excesso que representavam ainda importantes entraves burocráticos.

$\mathrm{E}$, no intento de se contornar os problemas dessa ordem em atenção às deficiências da reforma em 2003, cinco anos depois foi editado o Decreto-lei $n^{\circ} 226 / 2008$, que entrou em vigor em março de 2009, inclusive ampliando a desjudicialização que já havia sido implantada, razão esta pela qual Freitas o batiza como a "Reforma da Reforma" (2005, p.8).

Dessa sorte de acontecimentos, foram adotadas medidas como: i) ampliação da informatização do processo (o sistema CITIUS para juízes e advogados; e o sistema SISAAE/GPESE para os agentes de execução); ii) a criação de uma lista pública onde apareciam as execuções infrutíferas por inexistência de bens dos executados; iii) as reservas na atuação do juiz, como controlador do processo, tão somente acionado para solução de eventuais conflitos; e iv) a criação de uma Comissão para o controle externo da eficácia das execuções.

A principal mudança, no entanto, veio no sentido de se reforçar o papel do agente de execução, com o aumento de suas atividades para a prática de determinados atos materiais executivos, com o exercício de atribuições públicas para a realização de todas as diligências necessárias à boa e adequada tramitação do processo, sob o controle do juiz de execução.

Além do aumento de contingente e melhora da remuneração, também adveio a autorização legal para a livre destituição do agente de execução por parte do exequente, em decorrência de 
motivo relevante. Conforme observa Ribeiro, a relação entre ambos torna-se similar à de um mandato de direito privado, a despeito do desempenho de função pública envolvido, o que, inclusive, gerou uma divergência doutrinária quanto à natureza jurídica de tais profissionais (2013, p. 128).

Ocorreu, ainda, um favorecimento à tutela do interesse do exequente (Ribeiro, 2013) pelas medidas a seguir elencadas: i) publicidade da situação patrimonial do executado; ii) supressão do direito de o executado nomear bens à penhora; iii) busca e início da expropriação pelo bem mais acessível; e iv) presunção de titularidade de todos os bens na posse do executado.

Dentre os meios eletrônicos postos ao dispor do agente de execução para a realização de suas diligências a prol da satisfação dos créditos em excussão, tem-se: i) consulta eletrônica ao Banco de Portugal; ii) penhora eletrônica de saldos bancários; iii) penhora eletrônica de móveis e imóveis sujeitos a registro e tributações próprias, como IRS (Imposto sobre o Rendimento de pessoas Singulares), IRC (Imposto sobre o Rendimento de Pessoas Coletivas), IVA (Imposto sobre o Valor Acrescentado) etc.; iv) consulta eletrônica às bases de dados dos Serviços de Finanças; v) consultas eletrônicas às bases das Conservatórias (Civil, Comercial, Predial, de Automóveis, RNPC - Registo Nacional de Pessoas Colectivas etc.), Segurança Social e Caixa Geral de Aposentações, entre outras; e vi) consulta eletrônica ao registro informático de execuções.

Ressai evidente, desse modo, que, com as alterações propostas pelas Reformas de 2003 e 2008, o Estado português abandonou parcialmente, como dito alhures, o modelo tradicional de origem processualística romano-germânica, cuja matriz das atividades judiciárias é exclusivamente pública, a exemplo de outros Estados-membros da União Europeia, para a incorporação de um sistema de caráter misto (público-privado), mais similar ao da execução civil francesa.

Ulteriormente, vale ressaltar, o Novo Código de Processo Civil português (CPC/13), que entrou em vigor a partir de 1 de setembro de 2013 com o advento da Lei $n^{\circ} 41 / 2013$, a despeito de algumas mudanças pontuais concernentes à execução, manteve a essência das reformas de 2003 e 2008 anteriormente implantadas, fazendo com que passassem a coexistir de forma simultânea e harmônica, em razão da desjudicialização promovida na fase de excussão, as figuras do agente de execução, do juiz de execução e da Comissão para o Acompanhamento dos Auxiliares da Justiça (CAAJ).

\section{O PROCEDIMENTO EXECUTIVO LUSITANO: NOÇÕES GERAIS ${ }^{4}$}

O Novo Código de Processo Civil português de 2013 estabeleceu, conforme esclarece Farias (2015), dois ritos procedimentais para a execução por quantia, quais sejam, o ordinário, previsto no art. $724^{\circ}$, e seguintes, e o sumário, na esteira do art. $855^{\circ}$, e seguintes. Segundo Ribeiro, "As principais diferenças entre um rito e outro são, no sumário, a dispensa de despacho liminar, com recebimento e processamento do requerimento executivo inicial diretamente pelo agente executivo, e a realização de penhora antes da citação do executado" (2013, p. 141).

O rito sumário, utilizado em situações de excepcionalidade, em regra, é aplicado nos termos dos arts. $550^{\circ}$ e $626^{\circ}$, do Diploma Processual Civil, ou seja, nas execuções de obrigações certas, líquidas e exigíveis fundadas em decisão arbitral, requerimento de injunção com fórmula executória, obrigações pecuniárias garantidas por penhor ou hipoteca, decisões judiciais que não devam ser executadas nos próprios autos do processo de conhecimento e, por fim, títulos extrajudiciais de baixo valor.

O valor utilizado como referência para causas consideradas de pequeno valor é o dobro da alçada do Tribunal de primeira instância, hipótese esta em que é possível a utilização do rito sumário, ou seja, quando o valor da obrigação não o exceder. Esta quantia valorativa de alçada do

\footnotetext{
${ }^{4}$ Para um maior aprofundamento sobre as alterações advindas com o Novo Código de Processo Civil português de 2013, inclusive em relação à ação executiva e seus procedimentos, recomenda-se, respectivamente, a leitura de Freitas (2015) e de Farias (2015).
}

Revista de Direito Brasileira | Florianólopis, SC | v. 25 | n. 10 | p. 345-365 | Jan./Abr. 2020 
Tribunal de primeira instância, para efeitos cíveis, quando da edição do atual Código de Processo Civil de 2013, era de $€ \$ 5.000,00$ (cinco mil euros), consoante fixado no art. 44, da Lei $\mathrm{n}^{\circ}$ 62/2013, de 26 de agosto de 2013.

É vedado, porém, o uso do rito sumário quando a liquidação da obrigação exequenda não depender de simples cálculo aritmético no processo de execução, houver comunicabilidade do débito exequendo, em título executivo extrajudicial, entre o executado e seu cônjuge (segundo alegação do exequente), bem como nas excussões em face de devedor subsidiário que não tenha renunciado à execução prévia, além das hipóteses previstas nos arts.714. ${ }^{\circ}$ (referente à escolha da prestação na obrigação alternativa) e $715 .^{\circ}$ (relativa à obrigação condicional ou dependente de prestação), do CPC/2013.

Nos termos do art. $551^{\circ}$, do Código de Processo Civil de 2013, aplicam-se ao processo de execução subsidiariamente as disposições decorrentes do processo de conhecimento declaratório naquilo em que consonantes e, quanto ao rito sumário, são aplicáveis, também de forma subsidiária, as disposições compatíveis hauridas do rito ordinário.

Quanto à execução fundada em título executivo judicial condenatório, à luz das disposições do art. $626^{\circ}$, do CPC/13, são aplicáveis as prescrições havidas do art. $724^{\circ}$, e seguintes, do mesmo diploma, ou seja, o rito ordinário, ressalvados os casos em que a condenação se dê inserida no procedimento especial de despejo.

Cabe mencionar, ainda, que a excussão fundada em título executivo judicial condenatório para pagamento de quantia certa, à luz do previsto no art. $626^{\circ}, \mathrm{n}^{\circ} 2$, do Código de Processo Civil de 2013, deve seguir o rito sumário, não obstante as hipóteses de não cabimento deste rito preconizadas no $\mathrm{n}^{\mathrm{o}} 3$ do art. 550. ${ }^{\circ}$, do Código de Processo Civil de 2013, dando azo, mediante notificação do excutido a respeito da penhora, para que possa ser realizada oposição ao pagamento, se o caso.

\subsection{Ritos ordinário e sumário: o papel do agente de execução 5}

O processo de execução por quantia certa pelo rito ordinário, nos termos do art. $724^{\circ}$, do Código de Processo Civil de 2013, é iniciado com o requerimento executivo, dirigido diretamente ao Tribunal, o qual pode ser apresentado ou por meio de advogado, pela via eletrônica, ou por meio do próprio exequente, em via impressa, vez que se trata de um documento padrão, muito similar a uma petição inicial, em que são elencados os elementos essenciais, constantes deste mesmo dispositivo processual (art. $724^{\circ}, n^{\circ} 1$, letras "a" a " $k$ ", do Código de Processo Civil de 2013), tais como, v. g.: i) as partes; ii) o domicílio do advogado; iii) a causa de pedir, quando não constar do título; iv) o pedido; v) os valores da causa e da obrigação; vi) eventual pedido de dispensa de citação prévia do executado - quando necessário para a eventual manutenção de garantia patrimonial do crédito.

Além disso, deverão constar informações úteis à persecução do patrimônio do executado, como a localização de bens do devedor, passíveis de penhora. Para tanto, deve ser instruído com a cópia do título executivo e documentos comprobatórios dos bens eventualmente indicados para o prosseguimento da penhora, conforme previsto no art. $724^{\circ}, \mathrm{n}^{\circ} 4$, do Código de Processo Civil de 2013.

Concomitantemente, no requerimento executivo inicial é que o exequente indica qual o agente de execução escolhido, ou, conforme possibilitado nas hipóteses do art. $722^{\circ}, \mathrm{n}^{\mathrm{o}} 1$, do Código de Processo Civil de 2013, a escolha da condução do processo por um oficial de justiça.

\footnotetext{
${ }^{5}$ Neste tópico procede-se, propositalmente, à uma análise mais alongada em relação aos demais, vez que aqui objetivase uma descrição algo mais detida (embora reconheça-se breve) dos ritos processuais da execução civil portuguesa, de sorte a expor-se de maneira mais evidente a interação entre exequente, executado, Estado-juiz e a novel figura do agente de execução, verificando-se não mais a tradicional triangularização, mas uma hodierna quadrilarização da relação jurídica processual de excussão.
}

Revista de Direito Brasileira | Florianólopis, SC | v. 25 | n. 10 | p. 345-365 | Jan./Abr. 2020 
Em se tratando do agente de execução, o exequente já deve demonstrar o recolhimento das quantias devidas a este, a título de honorários e despesas, salvo quando dispensado pelas normas de assistência judiciária, as quais trazem como corolário a gratuidade de justiça.

Encaminha-se esse requerimento para a secretaria do Tribunal que, nos termos do art. $725^{\circ}$, do Código de Processo Civil de 2013, pode recusar o seu processamento quando verificar a falta de algum dos elementos do requerimento padrão supracitado. O não recebimento é recorrível ao juiz da execução, em única instância (Farias, 2015). Recebido o requerimento, este é distribuído e autuado, notificando-se o agente de execução de sua designação, inclusive sendo facultada a livre recusa da nomeação, nos termos do art. $720^{\circ}, \mathrm{n}^{\circ} 8$, do Código de Processo Civil de 2013.

Em seguida, é encaminhado ao juiz para, na terminologia legal, proferir despacho liminar (art. $723^{\circ}, \mathrm{n}^{\circ}$ 1, "a", do Código de Processo Civil de 2013), isto é, decisão interlocutória que pode ser de aperfeiçoamento (correção de vícios sanáveis), indeferimento (quando os vícios forem insanáveis ou não corrigidos tempestivamente pela parte) ou de citação (caso não haja irregularidades pendentes) (Ribeiro, 2013).

Nesse diapasão, dão ensejo ao indeferimento, nos termos do art. $726^{\circ}, \mathrm{n}^{\circ} \mathrm{s} 2$ e 4 , do Código de Processo Civil de 2013, os seguintes casos: i) ausência de pressupostos processuais ou irregularidades do requerimento executivo, quando não supridas pelo exequente; ii) manifesta falta ou insuficiência do título; iii) ocorrência de exceções dilatórias de conhecimento ex officio, não supríveis; iv) quando execução fundada em título negocial, seja manifesta a inexistência de fatos constitutivos e, ainda, a ocorrência de fatos impeditivos ou extintivos da obrigação exequenda, passíveis de conhecimento ex officio; e v) quando execução baseada em decisão arbitral, o litígio não pudesse ter sido submetido à via da arbitragem, quer por estar submetido, por lei especial, exclusivamente a tribunal judicial ou a arbitragem necessária, quer pelo direito controvertido não ter caráter patrimonial e não poder ser objeto de transação.

Por seu turno, a decisão citatória, consoante o previsto no art. $726^{\circ}, \mathrm{n}^{\circ} 6$, do Código de Processo Civil de 2013, dá azo para que o executado pague a dívida, ou, pretendendo, se oponha à execução, embargando-a no lapso de 20 (vinte) dias. A citação do cônjuge também pode ocorrer caso o exequente alegue a comunicabilidade da dívida constante de título diverso de sentença, em cumprimento ao prescrito no ${ }^{\circ} 2$ do art. $741^{\circ}$, do Código de Processo Civil de 2013.

Essas citações, vale salientar, são realizadas pelo agente de execução (art. $726^{\circ}, \mathrm{n}^{\circ} 8$, do Código de Processo Civil de 2013) e podem ser dispensadas, a pedido do exequente, quando houver fundado receio de perda da garantia patrimonial (art. $727^{\circ}$, Código de Processo Civil de 2013), conforme acima já mencionado.

Nesse caso, far-se-á(ão) a(s) citação(ões) após a penhora, com prazo de 20 (vinte) dias para, a partir e sobre ela(s), haver oposição de embargos tanto à execução como à constrição judicial por parte do(s) executado(s), se o caso, com a possibilidade de requerimento de substituição da penhora por caução idônea, procedimento este previsto tanto para o rito ordinário quanto para o rito sumário (art. $727^{\circ}, \mathrm{n}^{\circ}$ 4, c/c art. 856 ${ }^{\circ}$, do Código de Processo Civil de 2013).

Em se configurando ambas as hipóteses, serão realizadas, cumulativamente, as oposições de embargos à execução e à penhora, com automática suspensão da execução, sem prejuízo de reforço ou substituição de penhora, consoante supra explicitado.

Em se havendo acolhimento à(s) oposição(ões) de embargos à execução por parte do(s) executado(s), a excussão é extinta e o exequente responde pelos danos causados de forma culposa, com a inflição de multa de $10 \%$ (dez por cento) sobre a execução, ou da parte que tiver sido objeto $\mathrm{da}(\mathrm{s})$ oposição(ões), com seus limites mínimos e máximos sendo balizados legalmente (art. 858 ${ }^{\circ}$, do Código de Processo Civil de 2013).

No entanto, se a citação se der previamente à penhora, o art. $728^{\circ}, \mathrm{n}^{\mathrm{o}} 1$, do Código de Processo Civil de 2013, determina prazo de 20 (vinte) dias, a contar da citação, para a oposição de embargos à execução; em sendo logo após efetivada a penhora, são garantidos ao executado 
novamente 10 (dez) dias para apresentar oposição de embargos à penhora, a contar da notificação do ato constritivo, nos termos do art.785, $\mathrm{n}^{\circ}$ 1, do Código de Processo Civil de 2013.

Nesses casos, a execução somente será suspensa pela prestação da caução idônea por parte do executado, podendo, ainda, prosseguir sobre a parte da penhora em relação à qual não tenha ocorrido oposição de embargos (art. 785, $\mathrm{n}^{\circ} 3$, do Código de Processo Civil de 2013); caso haja acolhimento da oposição, cabe ao agente de execução proceder ao levantamento da penhora e ao cancelamento de eventuais registros (art. $785^{\circ}, n^{\circ}$ 6, do Código de Processo Civil de 2013).

O juiz de execução, todavia, poderá, ouvido o embargado, suspendê-la sem caução, se houver impugnação quanto à exigibilidade e liquidez da obrigação ou, excepcionalmente, houver identificação de sérias irregularidades por parte do magistrado, o que se tem com arrimo no art. $733^{\circ}, \mathrm{n}^{\circ}$ 1, "c", do Código de Processo Civil de 2013. As oposições sempre serão endereçadas ao juiz de execução e apresentadas, em regra, eletronicamente em apenso ao processo executivo principal (Ribeiro, 2013).

Quanto aos fundamentos de oposição de embargos à execução, estes se mostram variando a depender de se o título é consubstanciado em sentença judicial, sentença arbitral ou qualquer outro tipo de título, consoante as previsões insertas nos arts. $729^{\circ}$ a $731^{\circ}$, do Código de Processo Civil de 2013.

Geralmente se verifica a possibilidade de o executado atacar o título executivo em sua existência, validade e exequibilidade, bem como quanto à certeza, exigibilidade e liquidez da obrigação, questões de ordem pública referentes ao processo de execução e quaisquer fatos supervenientes ao processo de conhecimento (em regra, extintivos, modificativos e/ou impeditivos do cumprimento da obrigação objeto da excussão).

Excetuam-se, quanto a esse rol de matérias, os títulos não decorrentes de sentença, sobre os quais o executado pode alegar, além daquelas, quaisquer outras matérias dedutíveis no processo de conhecimento.

Dessa feita, o juiz poderá rejeitar, liminarmente, oposições de embargos à execução que sejam intempestivas, apresentarem fundamentos incompatíveis com a modalidade do título em que fundada a excussão e, ainda, que se revelarem manifestamente passíveis de rejeição $\left(\operatorname{art} .732^{\circ}, \mathrm{n}^{\circ}\right.$ 1, alíneas "a" a "c", do Código de Processo Civil de 2013).

Em caso de recebimento, o exequente é notificado para exercer o contraditório, agora na qualidade de embargado, também no prazo de 20 (vinte) dias, prosseguindo-se segundo o rito do processo comum declaratório, conforme previsto no art. $732^{\circ}, \mathrm{n}^{\circ} 2$, do Código de Processo Civil de 2013.

Vale salientar que da decisão que encerra os embargos caberá apelação, oportunidade em que deverão, também, ser impugnadas eventuais decisões interlocutórias proferidas ao longo deste procedimento, conforme art. $853^{\circ}, \mathrm{n}^{\circ} 1$, do Código de Processo Civil de $2013^{6}$.

Caso seja mantida a execução em razão de uma das hipóteses contidas nas alíneas "a" a "d" do $\mathrm{n}^{\circ} 1$ do art. $748^{\circ}$ do Código de Processo Civil de 2013 (como, e. g., a de rejeição dos embargos à execução que a tenham suspendido), deve haver notificação por parte da secretaria ao agente de execução para que inicie os atos e diligências inerentes à penhora, o que fará respeitando uma cláusula geral de proporcionalidade e adequação entre o patrimônio do devedor e o direito de adimplemento do credor, consoante regulado pela Portaria $n^{\circ}$ 282/2013, do Ministério da Justiça lusitano.

\footnotetext{
${ }^{6}$ Verifica-se, aí, uma clara diferença procedimental em relação ao Código de Processo Civil brasileiro de 2015, vez que manteve, para o processo de excussão e seus incidentes, o recurso de agravo de instrumento das decisões interlocutórias, ao contrário do que visto no rito do processo de conhecimento, pátrio e português (no caso deste, estendido aos procedimentos ou incidentes de natureza declaratória inseridos na tramitação da ação executiva), em que as questões relativas às impugnações de decisões interlocutórias são apenas devolvidas ao juízo ad quem quando da eventual interposição de apelação.
} 
Os agentes de execução, para tanto, são responsáveis pela administração e alimentação de dados processuais junto ao sistema chamado "registo informático de execuções", conforme previsto no artigo retrocitado, em seu $n^{\circ} 2$, e regulado pelo art. $58^{\circ}$, da Portaria $n^{\circ} 282 / 2013$, do Ministério da Justiça lusitano.

Trata-se, em verdade, de um banco de dados em que são inseridas informações dos executados que sejam úteis à persecução de seu patrimônio, bem como notícias sobre processos de execução pendentes, findos ou suspensos em face de si, além de dados sobre penhoras bem sucedidas e fracassadas, lista de bens já penhorados, dentre outras circunstâncias relevantes (Ribeiro, 2013).

O próprio agente de execução, antes do início dos atos de penhora, deverá, de conseguinte, realizar busca nesse sistema de dados a respeito do excutido, e seu patrimônio, com o fulcro de adotar determinada estratégia e, a depender do resultado do que encontrar nas informações compiladas, verificar se a postura previamente eleita é conveniente e oportuna ao caso ou se outra deverá ser tomada em função de ser mais adequada à realidade descortinada.

E isso porquanto, exempli gratia, encontre outras execuções em andamento em face do mesmo devedor, ou mesmo encerradas nos últimos três anos, sem integral cumprimento, segundo a inteligência do previsto no artigo $748^{\circ}, \mathrm{n}^{\circ} 3$, c/c art. $749^{\circ}, \mathrm{n}^{\circ} 1$, ambos do Código de Processo Civil de 2013, deverá o agente de execução buscar bens patrimoniais do executado por meio de sistemas informatizados sob gestão da Administração Pública, nos quais se encontrem informações tributárias, de segurança social, registros cíveis, imóveis, automóveis, atividades comerciais, dentre outros dados aos quais se tem acesso, independentemente de autorização judicial.

O resultado é comunicado ao exequente que, assim, também poderá realizar diligências próprias para instruir o agente de execução, em prazo de 10 (dez) dias, sobre a localização de eventual patrimônio; não sendo possível obter-se qualquer informação sobre os bens do excutido, ou sua localização concreta, segue-se a extinção da execução (artigo $748^{\circ}, n^{\circ} 3$, segunda parte, do Código de Processo Civil de 2013).

Após nova notificação do executado, o mesmo é incluído em uma lista pública de execuções frustradas, nela permanecendo pelo prazo de 5 (cinco) anos ou até que salde sua dívida. Esta lista pública de execuções é regulamentada pela Portaria no 279/2013, do Ministério da Justiça lusitano, e consiste em uma lista eletrônica de dados (assim, restritivos ao crédito) que funciona como um mecanismo auxiliar para se detectar situações de inadimplência, cuja cobrança infrutífera poderá prevenir, de conseguinte, novos acionamentos injustificados de execuções à luz do conhecimento público dos elementos quanto à capacidade financeira do devedor (Ribeiro, 2013).

Portanto, se o agente de execução encontra outra execução em andamento em face do mesmo executado, deve verificar se é caso de remeter o requerimento executivo para o outro processo a fim de se estabelecer um concurso de créditos, consoante a previsão contida no art. $748^{\circ}$, n 4, do Código de Processo Civil de 2013, aplicável à espécie.

Caso o agente de execução encontre patrimônio, deve-se realizar a penhora começando pelos bens de mais fácil realização quanto ao valor e que se mostrem adequados à satisfação do débito em excussão, malgrado respeitando uma ordem legalmente estabelecida ante o previsto no art. $751^{\circ}, \mathrm{n}^{\mathrm{o}} 1$, do Código de Processo Civil de 2013, observando-se as indicações do exequente (constantes do rol inserto no requerimento inicial) sobre os bens que pretende ver prioritariamente penhorados, salvo se violarem norma de cogência absoluta impeditiva da penhora, ofenderem o princípio da sua proporcionalidade ou infringirem de modo manifesto a ordem dos bens a serem penhorados (conforme disposto no $\mathrm{n}^{\mathrm{o}} 2$ deste artigo).

De fato, a preferência legal e dos exequentes se inicia com os depósitos bancários, a exemplo do que também ocorre no Brasil, sendo que o próprio agente de execução pratica de forma eletrônica os atos necessários para penhorá-los, ante o prescrito no art. $780^{\circ}, \mathrm{n}^{\circ} \mathrm{s} 1$ a 14, do Código de Processo Civil de 2013, em combinação ao disposto na Secção IV - "Disponibilização de 
informação e penhora de depósitos bancários" (arts. $17^{\circ}$ e $18^{\circ}$ ), da Portaria $n^{\circ}$ 282/2013, do Ministério da Justiça lusitano.

Caso frustrada a tentativa de penhora eletrônica de valores em contas bancárias, também é possível, por meios eletrônicos, o agente de execução penhorar bens móveis sujeitos a registro e imóveis, remetendo-se comunicado para o órgão de registro competente, de acordo ao que disposto no art. $755^{\circ}, \mathrm{n}^{\circ} 1, \mathrm{c} / \mathrm{c}$ art. $768^{\circ}, \mathrm{n}^{\circ} 1$, ambos do Código de Processo Civil de 2013. De outro lado, os bens móveis não sujeitos a registro serão penhorados por meio de sua apreensão e envio imediato a depósito (art. $764^{\circ}, \mathrm{n}^{\circ}$ 1, do Código de Processo Civil de 2013).

$\mathrm{O}$ agente de execução, ou pessoa que ele indicar - inclusive o executado, se o exequente anuir -, poderá ser o fiel depositário dos bens móveis penhorados e não sujeitos a registro, à luz da previsão constante do art. $764^{\circ}, \mathrm{n}^{\circ} \mathrm{s} 1$ e 2 , e art. $756^{\circ}, \mathrm{n}^{\circ} 1$, caput, c/c art.772 , todos do Código de Processo Civil de 2013.

Se, por algum motivo, a penhora se caracterizar ilegal, quer por violação aos seus limites objetivos - por recair sobre bens que não poderiam sofrer constrição judicial (art.736", "a" a "g", e art. $737^{\circ}, \mathrm{n}^{\circ} \mathrm{s}, 1$ a 3, do Código de Processo Civil de 2013) -, quer por violação aos limites subjetivos (por exemplo, bens que não são do executado), é possível sua impugnação por objurgação direta mediante petição do executado, ou de terceiro, sem prejuízo da oposição de embargos deste ou à penhora (art. 764, no 3, do Código de Processo Civil de 2013).

A defesa, em casos tais, pode ser, assim, deduzida de forma incidental na própria execução, por intermédio de simples requerimento - em dita objeção de pré-executividade (repita-se, dado o previsto no art. 764, n ${ }^{\circ}$ 3, do Código de Processo Civil de 2013) -, em que pese a presunção de propriedade do executado quanto aos bens em sua posse, na hipótese, passível de ser ilidida perante o juiz de execução pela via documental, de sorte a, assim, comprovar-se inequivocamente o referido direito sobre eles, sem prejuízo da faculdade de dedução dos embargos de terceiro.

Os embargos à penhora também podem ser deduzidos sob os fundamentos dispostos no art. $784^{\circ}, \mathrm{n}^{\mathrm{o}} 1$, "a" a "c", do Código de Processo Civil de 2013, onde tem lugar o incidente quando for constatada a inadmissibilidade de penhora dos bens apreendidos ou da extensão com que ela foi realizada, bem como em se tratando de bens que apenas subsidiariamente responderiam pela dívida exequenda, ou, ainda, quando não responderiam pela dívida exequenda, nos termos do direito substantivo.

Além desta via, há, ainda, a possibilidade de se aduzir-se defesa ao ato de constrição por meio de ações de conhecimento autônomas, como, $v . g$., não apenas os ditos embargos de terceiro, mas, outrossim, das ações reivindicatórias com fundamento no direito de sequela.

Doutro bordo, a alienação dos bens penhorados, quando necessária, conta com uma ampla gama de modalidades, conferida pelo art. $811^{\circ}, \mathrm{n}^{\circ}$ 1, "a" a "g", do Código de Processo Civil de 2013, a saber: i) venda mediante propostas em carta fechada; ii) venda em mercados regulamentados; iii) venda direta a pessoas ou entidades que tenham direito a adquirir os bens; iv) venda por negociação particular; v) venda em estabelecimento de leilões; vi) venda em depósito público ou equiparado; e vii) venda em leilão eletrônico.

Em geral, o agente de execução escolhe a regra (ouvidos o exequente e executado), com exceção da venda mediante proposta em carta fechada (por se tratar de modalidade especificamente regulada) que se dá por meio do juiz da execução, quando se tratar de bem imóvel, ou, de estabelecimento comercial, se assim por ele determinado (nos termos do art $800^{\circ}, \mathrm{n}^{\circ} 3$, inclusive c/c art. 829..$^{\circ}$ do Código de Processo Civil de 2013). Quando não houver ressalvas, preferir-se-á o leilão eletrônico, consoante o art. 812, nº 1, do Código de Processo Civil de 2013.

No mais, é de se comentar que extinta a execução por qualquer dos motivos alhures referidos - evidencie-se, in casu, a extinção pela satisfação da execução e a supracitada possibilidade de extinção por nulidade da lide, conforme o resultado das investigações por parte do agente de execução -, o fato é comunicado ao Tribunal pelo agente, o qual aguarda o decurso dos prazos recursais e demais formalidades, e realiza o arquivamento eletrônico dos autos, sem 
necessidade de intervenção judicial, conforme designação do art. 849 ${ }^{\circ}$, do Código de Processo Civil de 2013.

Quanto ao rito sumário, nos casos em que houver lugar para a sua incidência, ante os termos do art. $855^{\circ}, \mathrm{n}^{\circ} \mathrm{s} 1$ a 5, do Código de Processo Civil de 2013, o requerimento executivo é encaminhado diretamente, por via eletrônica, para o agente de execução. Nesta ocasião, ao agente, em não recusando a designação, incumbe o juízo de admissibilidade acerca da regularidade formal do requerimento (a exemplo do que previsto no rito ordinário para a Secretaria do Tribunal), podendo, fundamentadamente e se for o caso, recusá-lo nos moldes do art. $725^{\circ}$, do Código de Processo Civil de 2013 (art. 855 , n² 2, "a", do Código de Processo Civil de 2013).

Nesse sentido, se porventura, no mesmo juízo, o agente de execução identificar indícios de alguma das hipóteses de indeferimento, tais como aquelas previstas no art. $724^{\circ}, \mathrm{n}^{\circ} \mathrm{s} 2$ e 4 , do Código de Processo Civil de 2013, e que possam ser eventualmente apreciadas pelo juiz no rito ordinário (art. $723^{\circ}, \mathrm{n}^{\circ}$ 1, do Código de Processo Civil de 2013), ou então tenha dúvidas sobre o cabimento do rito sumário, deverá remeter os autos ao próprio juiz da execução para deliberação e decisão (Ribeiro, 2013).

Recebido o requerimento, com previsão no $\mathrm{n}^{\circ} 4$ do art. $855^{\circ}$, do Código de Processo Civil de 2013, se o exequente não indicar bens penhoráveis, se forem negativas as consultas prévias para penhora e se restarem frustradas as tentativas de citação pessoal do executado, não se tratará de uma das hipóteses de possível citação por edital, mas de extinção da excussão por parte do agente de execução.

Todavia, sendo localizados e penhorados os bens, o executado é citado (atividades, estas, a cargo do agente), oportunidade em que poderá se opor, simultaneamente, à penhora e à execução por meio dos embargos. Desde logo, vez que existente a penhora, os embargos têm efeito suspensivo independentemente de caução (Ribeiro, 2013).

E, diante de tal circunstância, a exemplo do que asseverado alhures para o rito ordinário, no bojo do rito sumário, também o eventual acolhimento dos embargos à execução em face do executado implica a responsabilidade do exequente por eventuais danos culposos causados pela ausência da prudência, consoante padrão de normalidade exigida para os atos processuais, sendo devido a prol do excutido, em tal hipótese, multa de $10 \%$ (dez por cento) sobre o valor da execução, conforme previsto no art. $858^{\circ}$, do Código de Processo Civil de 2013, igualmente aplicável à espécie.

\section{A experiência brasileira desjudicializante executiva civil: o exemplo da Justiça do} Trabalho

Verificados de forma mais detida em relação aos demais tópicos (malgrado, reconheça-se, brevemente) os procedimentos ordinário e sumário do processo de execução civil português, o que se objetivou foi expor-se a interação da novel função do agente de execução com as dos demais atores processuais tradicionais (exequente, executado e Estado-juiz), de sorte a, com isso, a partir da exposição que se fará neste tópico a respeito da pioneira experiência brasileira desjudicializante executiva civil (haurida da Justiça do Trabalho), ter-se possibilitado um comparativo entre tais ordenamentos jurídicos, e suas execuções, para, assim, aproveitarem-se exemplos estrangeiros que venham a agregar ao modelo pátrio maiores celeridade, eficiência e efetividade para o adimplemento dos créditos pretendidos em juízo.

No caso brasileiro das execuções civis, a desjudicialização é muito mais tímida à que verificada no processo civil executivo lusitano, inexistindo tal tendência no processo judicial pátrio de forma tão marcante como ocorrido em Portugal desde 2003. A respeito, inclusive, Farias converge ao asseverar que 
No Brasil, a desjudicialização da execução civil ainda não existe como opção para adaptar-se à realidade brasileira, tal como despontou em Portugal. Nunca chegou a ser introduzida no sistema processual civil de execução brasileiro uma desjudicialização no bojo de um processo judicial propriamente dito. O que pode ser apontado, e ainda de forma discreta, são indícios de desjudicialização, mas nada comparado ao sistema existente no processo civil executivo português (2015, p.111).

Em verdade, não obstante a experiência desbravadora do Decreto-lei n ${ }^{\circ}$ 58/37 (art. 14), ao permitir a rescisão, no seio do registro imobiliário, dos contratos de promessa de compra e venda celebrados em seus termos (isto é, sem a intervenção do Poder Judiciário), o que se tem, inclusive desde a década de 1960, são meros indícios ou tentativas nacionais de desjudicialização em situações ou áreas pontuais e esparsas, sobre questões que não se verificam específicas ou mesmo totalmente relacionadas às excussões.

Vale salientar que as contribuições dessas retromencionadas experiências nacionais de desjudicialização, em si, não excederam às já oferecidas pela arbitragem, medição, conciliação ou transação em termos de eficiência, celeridade e concreção dos direitos envolvidos ${ }^{7}$, consoante os exemplos retirados da Lei $n^{\circ} 4.591 / 64$, do Decreto-lei $n^{\circ} 70 / 66$, da Lei $n^{\circ} 9.514 / 97$, da Lei $n^{\circ}$ 11.441/07 e do Projeto de Lei $\mathrm{n}^{\circ} 2.412 / 07$, com os seus respectivos apensos de $\mathrm{n}^{\circ} 5.080$ e 5.081 (Farias, 2015), como, ainda, das Leis $n^{\circ} 9.492 / 97, n^{\circ} 10.931 / 04, n^{\circ} 11.977 / 2009$ e $n^{\circ} 12.100 / 09$.

Tais exemplos, em linhas gerais, versam, ou sobre tentativas de se introduzir um modelo de execução extrajudicial sobre alguns temas específicos ${ }^{8}$, ou sobre a possibilidade de realização pela via administrativa de alguns procedimentos voltados a direitos reais, de família e sucessórios ${ }^{9}$.

Atualmente, na esteira dessa tendência desjudicializante brasileira, o CNJ - Conselho Nacional de Justiça tem promovido algumas medidas no sentido de melhorar a celeridade e eficiência dos processos de execução civil, de modo a aumentar o efetivo cumprimento dos créditos inadimplidos. Em tal diapasão, tem-se a inovadora Meta $n^{\circ} 5 / 2011$, do CNJ (2011), que versa sobre a criação de Núcleos de Apoio à Execução no âmbito da Justiça do Trabalho, locus de um dos maiores gargalos existentes quanto à celeridade e eficiência para a satisfação dos créditos em cumprimento dos julgados.

Com efeito, desde sua criação para o planejamento, coordenação e controle das atividades do Judiciário, em atenção ao previsto no art. 103-B, da Constituição Federal de 1988, o CNJ Conselho Nacional de Justiça revela intensa preocupação com a eficiência, efetividade, celeridade e razoável duração dos processos judiciais, princípios constitucionais que busca alcançar mediante a instituição de padrões de produtividade por intermédio de metas que impõe ${ }^{10}$.

De conseguinte, à luz da supramencionada Meta $n^{\circ}$ 5/2011 estipulada expressamente pelo CNJ - Conselho Nacional de Justiça para as excussões laborais na esfera da Justiça do Trabalho,

\footnotetext{
${ }^{7}$ A respeito da utilização da conciliação e da mediação como instrumentos de desjudicialização das relações sociais, recomenda-se a leitura de Milarez (2013).

${ }^{8}$ Como, $e$. g., matéria fiscal, dívida hipotecária, alienação fiduciária de bens imóveis ou a alienação de direitos de contratantes ou adquirentes inadimplentes inseridos em condomínios, edificações ou incorporações imobiliárias (cujas inconstitucionalidades alegadas, em regra, são voltadas para a ausência ou mitigação do contraditório e ampla defesa que encerram, a evidenciar uma teórica e defesa autotutela).

${ }^{9}$ Como, v. g., protesto, retificação de área, usucapião, retificação de assentos civis, inventário e partilha de bens, além de separação e divórcio consensuais. Aliás, nesta área do Direito de Família, já se tem notícia de uma tentativa desjudicializante por parte da Justiça de Pernambuco (Provimento $\mathrm{n}^{\circ}$ 06/2019, da Corregedoria-geral) para possibilitar a realização do divórcio dito unilateral ou impositivo, ou seja, litigioso extrajudicial, o que, todavia, já tem sido inquinado de inconstitucional e ilegal à luz do previsto no art. 226, § $6^{\circ}$, da Constituição Federal de 1988, c/c art. 733, do Código de Processo Civil de 2015, mesmo após a Emenda Constitucional nº 66.

${ }^{10}$ A respeito deste assunto, especificamente quanto ao CNJ - Conselho Nacional de Justiça e as metas que estipula como forma de controle e parametrização da eficiência para um equilíbrio entre a razoável duração do processo e a efetivação das prestações jurisdicionais, aconselha-se a crítica de Demarchi (2011).

Revista de Direito Brasileira | Florianólopis, SC | v. 25 | n. 10 | p. 345-365 | Jan./Abr. 2020
} 
foi editada a Resolução no 138/2014, por parte do CSJT - Conselho Superior da Justiça do Trabalho, visando, em consonância à almejada excelência de produtividade da atividade judiciária e efetividade dos créditos trabalhistas, dispor sobre os NPP's - Núcleos de Pesquisa Patrimonial no interior dos Tribunais Regionais do Trabalho, definindo seus objetivos de atuação ante a fixação de diretrizes gerais de cunho nacional.

Dentre as competências de apoio judiciário à efetividade da execução trabalhista especificadas para os NPP's nessa Resolução no 138/2014, do CSJT - Conselho Superior da Justiça do Trabalho, estão, por exemplo, a promoção da identificação de patrimônio a fỉm de garantir a excussão, a atribuição a executantes de mandados voltados a coleta de dados e outras diligências de inteligência, bem como a elaboração de estudos sobre técnicas de pesquisa, investigação e avaliação de dados, além de mecanismos e procedimentos de prevenção, obstrução, detecção e de neutralização de fraudes à execução, praticando todos os atos procedimentais necessários ao regular andamento dos processos, e exercendo outras atividades inerentes à sua finalidade (art. $2^{\circ}$, I, V, VI, X e XI).

Tais competências, de conseguinte, muito se assemelham às do agente de execução do processo civil português (a seu turno reguladas pela Portaria n ${ }^{\circ}$ 282/2013, do Ministério da Justiça de Portugal), como visto alhures, embora por intermédio não de um particular em colaboração com a Administração (e em exercício de munus público), mas de um órgão próprio e específico do Poder Judiciário, o NPP - Núcleo de Pesquisa Patrimonial (no interior dos Tribunais Regionais do Trabalho), imbuído que é de lograr a efetividade das execuções trabalhistas em conjunto com a atuação do oficial de justiça, assim, dinamizada também quando em parceria com o próprio exequente.

Com isso, malgrado seja possível se verificar uma influência das inovações hauridas de um hodierno processo civil cooperativo, inclusive tomando-se o exemplo do Direito português - não obstante as necessárias adaptações ao Direito pátrio em uma área cujo gargalo para a celeridade e razoável duração das execuções é um ponto nevrálgico, qual seja, a do Direito do Trabalho -, resta evidente que a opção brasileira para a superação das dificuldades mais relevantes para a eficiente concretização da prestação jurisdicional excutória (tanto de natureza jurídica, como de ordem material) tem sido a criação de competências e órgãos especializados, em clara desconcentração e especialização das atividades judiciárias correlatas, e não a adoção da desjudicialização com transferência das funções a particulares.

E, corroborando essa tendência desconcentrante e especializante das atividades judiciárias vocacionadas para a efetivação dos créditos em excussão judicial, in casu, de cunho laboral, no seio do Direito Trabalhista nacional descortina-se uma realidade cooperativa por intermédio da edição do Provimento CGJT n ${ }^{\circ}$ 01/2018, da Corregedoria-Geral da Justiça do Trabalho, ao regulamentar e padronizar os PRE's - Procedimentos de Reunião de Execuções ${ }^{11}$ em face de grandes devedores, a cargo de juízos centralizadores ${ }^{12}$ instituídos conforme a organização judiciária de cada Tribunal Regional, criando-se, assim, uma sinergia proveitosa não apenas em favor da celeridade, razoável duração e efetivação processuais, em atenção ao art. $5^{\circ}$, LXXVIII, da Constituição Federal de 1988, mas também dos primados da eficiência administrativa e da

\footnotetext{
${ }^{11}$ De fato, o PRE - Procedimento de Reunião de Execuções, na esfera da Justiça do Trabalho, é constituído pelo PEPT - Plano Especial de Pagamento Trabalhista, cujo objetivo é o pagamento parcelado do débito, e pelo REEF - Regime Especial de Execução Forçada, o qual é voltado para a expropriação do patrimônio dos devedores a prol da coletividade dos credores.

${ }^{12}$ Dentre as atribuições dos juízos centralizadores do PRE - Procedimento de Reunião de Execuções, vale ressaltar, estão o acompanhamento do seu processamento, comunicando-se com o órgão responsável pela gestão do procedimento (consoante estabelecido pela organização administrativa do correlato Tribunal Regional do Trabalho), a identificação dos grandes devedores e, se o caso, seus grupos econômicos (conforme verificado no âmbito do Tribunal Regional do Trabalho), a fim de se poder reunir suas execuções em andamento pela instauração do REEF - Regime Especial de Execução Forçada (com auxílio das ferramentas eletrônicas dispostas para tanto), bem como coordenar ações e programas que visem à efetividade da execução.
}

Revista de Direito Brasileira | Florianólopis, SC | v. 25 | n. 10 | p. 345-365 | Jan./Abr. 2020 
economia processual, inclusive à luz do disposto no art.28, caput e parágrafo único, da Lei $\mathrm{n}^{\circ}$

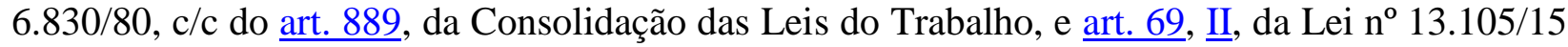
(Código de Processo Civil).

Para tanto, os esforços alcançam também os próprios Tribunais Regionais do Trabalho, podendo-se citar, como exemplo, o Tribunal Regional do Trabalho da $2^{\text {a }}$ Região (em razão de ser o maior do país), com seu Provimento GP/CR 2/2019 que disciplina o funcionamento do JAE Juízo Auxiliar em Execução ${ }^{13}$ e do NPP - Núcleo de Pesquisa Patrimonial em seu bojo, sendo isso se dando em conjunto com o seu Ato GP/CR 05/2017, o qual, ao instituir a UAO - Unidade de Apoio Operacional, dentre outras coisas, prescreve em seu art. 11, "a", ao fixar atribuições, uma sinergia de atuação com o oficial de justiça de forma similar ao que se tem no Direito Processual Civil português com o agente de execução.

A dita UAO - Unidade de Apoio Operacional ${ }^{14}$ criada no Tribunal Regional do Trabalho da $2^{\text {a }}$ Região como sendo subordinada à Secretaria Geral Judiciária, de fato, é o órgão responsável por fomentar a melhor e maior harmonia e complementariedade de atuação entre o JAE e o Oficial de Justiça Avaliador Federal (especialidade do ocupante do cargo de Analista Judiciário para a área judiciária), cujas atribuições lembram, em conjunto com as acima comentadas dos NPP's, às do agente de execução português, vez que desempenha atividades relacionadas com a execução de mandados e demais atos processuais correlatos (em processos físicos e eletrônicos), na forma estabelecida pela legislação processual civil, penal, trabalhista e demais leis especiais ${ }^{15}$.

Dessa forma, a análise das medidas implementadas na Justiça do Trabalho em busca da eficiência na concreção dos créditos trabalhistas em execução, em si, revela um exemplo de atuação que, com a desconcentração e especialização das atividades judiciárias, potencializadas pelo uso das ferramentas eletrônicas de consultas e bloqueios judiciais, tende a ser replicado em outras áreas da Justiça pátria com problemas semelhantes, o que pode ser ainda mais potencializado em se reforçando e valorizando a figura do tradicional oficial de justiça com os exemplos extraídos do processo de execução civil português, maxime quanto à competência hoje lá exercida pelo agente de execução.

\section{CONCLUSÃO}

O legislador português, desde suas reformas legislativas de 2003 e 2008, na sequência mantidas em sua essência pelo Código de Processo Civil de 2013, diante das atuais competências da relação jurídica executiva quadrilarizada no Direito Processual Civil português, claramente adota uma alteração de modelo quebrando a tradição processualística romano-germânica, tendo

\footnotetext{
${ }^{13}$ Coordenado pela Corregedoria Regional, com a designação de um Juiz do Trabalho Substituto (funcionando como Juiz Auxiliar em Execução junto às Varas do Trabalho da $2^{\mathrm{a}}$ Região) para atuar como seu responsável (segundo Portaria), o JAE - Juízo Auxiliar em Execução atuará acompanhando e processando o plano prévio de liquidação de execuções, promovendo a reunião temporária de execuções (segundo um quantitativo mínimo) em face de um mesmo grande devedor ou grupo econômico, mediante sua prévia identificação, por meio da instauração do REEF - Regime Especial de Execução Forçada, bem como coordenar ações e programas que visem à efetividade da execução, a exemplo do que preconizado pelo Provimento CGJT n ${ }^{\circ}$ 01/2018, da Corregedoria-Geral da Justiça do Trabalho.

${ }^{14}$ A UAO - Unidade de Apoio Operacional, composta por duas subunidades de apoio, o PS - Posto de Serviços e a CM - Central de Mandados, funcionará apenas na sede de cada uma das 05 (cinco) circunscrições (a saber: São Paulo; Osasco e Região; São Bernardo do Campo e Região; Guarulhos e Região; e Baixada Santista), conforme definidas no Regimento Interno do Tribunal Regional do Trabalho da $2^{\mathrm{a}}$ Região.

${ }^{15}$ As atribuições dos Oficiais de Justiça Avaliadores Federais têm por escopo executar preferencialmente os mandados virtuais, cumprindo ordem judicial relativa à pesquisa e à constrição de bens do executado por meio das ferramentas eletrônicas (ARISP, BACENJUD, CDT, CENSEC, CNIB, INFOJUD, INFOSEG, JUCESP, RENAJUD, SIMBA e outros) oferecidas pelos convênios assinados por esta Justiça com entidades ou órgãos específicos (Receita Federal, Associação dos Registradores Imobiliários, SERASA S/A, Associação Comercial, Banco Central do Brasil etc), sem prejuízo de diligências locais.
}

Revista de Direito Brasileira | Florianólopis, SC | v. 25 | n. 10 | p. 345-365 | Jan./Abr. 2020 
por supedâneo as experiências de outros Estados da União Europeia, ao introduzir um arquétipo de cunho misto (público-privado), desjudicializado e colaborativo na execução civil.

O rompimento da exclusividade do desempenho das atividades judiciárias procedimentais (de cunho não jurisdicional) por parte do Estado-juiz, em si, dá lugar a uma atuação cooperativa intensa entre as partes no processo executivo civil português, a exemplo do que já ocorre no Brasil, malgrado em proporções muito menos acentuadas, posto inexistir a figura do terceiro particular (o agente de execução) para maiores eficiência processual e celeridade de tramitação com, assim, efetividade dos direitos de crédito segundo uma razoável duração do processo.

A contemporânea atuação dos envolvidos no processo de excussão civil português, principalmente do agente de execução em sinergia com os demais, traz uma desjudicialização que investe na figura remodelada do particular em colaboração com a Administração (Estado-juiz, in casu), o que, no Brasil, resta atenuado pela desconcentração e especialização das atividades judiciárias, com a redistribuição de competências, ou em antigas figuras como a do oficial de justiça, ou em novos órgãos auxiliares como o NPP e o JAE, sendo potencializadas tais atividades, como em Portugal, pelo uso das ferramentas eletrônicas de consultas e bloqueios judiciais.

$\mathrm{Na}$ experiência brasileira, conforme se extrai da análise dos ritos processuais ordinário e sumário de execução civil portuguesa, muitas das atribuições hoje pertencentes ao agente de execução já se verificam sendo enfeixadas na figura do Oficial de Justiça Avaliador Federal, com o auxílio de outros órgãos (NPP, JAE e UAO), no bojo da Justiça do Trabalho, com o fito de galgarem-se maiores razoável duração, celeridade e eficiência processuais, segundo um padrão de excelência previamente estabelecido para a concreção dos créditos laborais.

Dessa maneira, conclui-se também que o exemplo da execução civil portuguesa, guardadas as devidas adaptações constitucionais e legais necessárias, pode ter seu aproveitamento para o ordenamento jurídico pátrio sendo aprofundado, valorizando-se ainda mais as designações do oficial de justiça em outras áreas além do Direito Trabalhista, capacitando-o para os novos misteres na busca da almejada concreção dos créditos judicialmente pretendidos.

Para tanto, todavia, revela-se necessário a criação de toda uma estrutura que viabilize, de um lado, um eficiente e efetivo desempenho destas novas atribuições públicas processuais de excussão, e, de outro, que garanta a segurança jurídica quanto ao patrimônio do devedor e seu direito de ampla defesa e contraditório.

\section{REFERÊNCIAS}

ARAGÃO, Alexandre Santos de. Princípio da eficiência. Revista de direito administrativo. Rio de Janeiro: Fundação Getúlio Vargas, nº 237, jul./set. 2004, p. 1-6.

CAMPILONGO, Celso Fernandes. O Judiciário e a democracia no Brasil. Revista USP. São Paulo, Coordenadoria de Comunicação Social (CCS), no 21, 1994, p. 116-125. Disponível em: http://www.revistas.usp.br/revusp/article/view/26940/28718. Acesso em: 19.11.2017.

CAMPOS, Cleiton de; MEYER-PFLUG, Samantha Ribeiro. A reforma do Poder Judiciário e o princípio da eficiência. Revista de Direito Brasileira. Florianópolis: CONPEDI, v. 6, nº 3, set./dez. 2013, p. 304-314. Disponível em: https://www.indexlaw.org/index.php/rdb/article/view/2752/2640. Acesso em: 19.11.2017.

CNJ - Conselho Nacional de Justiça. Meta no 5 - 2011 (Justiça Trabalhista): criar um núcleo de apoio de execução. 2011. Disponível em: http://www.cnj.jus.br/images/metas_judiciario/2011/meta5/meta_5_2011.pdf. Acesso em: 19.11.2017. 
DEMARCHI, Clóvis. As metas do CNJ: controle e parâmetro para o prazo razoável do processo e o princípio da eficiência. Revista Eletrônica Direito e Política. Itajaí: UNIVALE, v. 6, no 2, $2^{\circ}$ quadrimestre 2011, p. 693-709. Disponível em: https://siaiap32.univali.br/seer/index.php/rdp/article/viewFile/6071/3338. Acesso em: 19.11.2017.

FARIAS, Rachel Nunes de Carvalho. Desjudicialização do processo de execução: o modelo português como uma alternativa estratégica para a execução civil brasileira. Curitiba: Juruá, 2015.

FREITAS, José Lebre de. O primeiro ano de uma reforma executiva adiada. In: Balanço da reforma da acção executiva (encontro anual de 2004). Coimbra: Coimbra Editora, 2005, p. 2128.

FREITAS, José Lebre de. Sobre o novo Código de Processo Civil (uma visão de fora). In: ANDRADE, Érico; DIAS, Maria Tereza Fonseca (coord.). Tensões entre o público e o privado. Encontro luso-brasileiro de Direito, 2, 2013, Belo Horizonte. Anais [...]. Belo Horizonte: Fórum, 2015, p. 117-148.

MELLO, Celso Antônio Bandeira de. Curso de direito administrativo. São Paulo: Malheiros Editores, 34 ${ }^{\mathrm{a}}$ ed., 2019.

MILANEZ, Márcia Maria. A conciliação e a mediação como instrumentos para a desjudicialização das relações sociais. Revista JC - Justiça \& Cidadania. Rio de Janeiro: Editora JC, $\mathrm{n}^{\mathbf{0}}$ 158, out. 2013, on-line. Disponível em: http://www.editorajc.com.br/conciliacao-mediacao-instrumentosdesjudicializacao-relacoes-sociais/. Acesso em: 19.11.2017.

MITIDIERO, Daniel. Colaboração no processo civil: pressupostos sociais, lógicos e éticos. In: MARINONI, Luiz Guilherme; BEDAQUE, José Roberto dos Santos (coord.). Temas atuais de direito processual civil - vol. 14. São Paulo: Editora Revista dos Tribunais, $2^{a}$ ed., 2011.

MONCADA, Luís S. Cabral de. A relação jurídica administrativa: para um novo paradigma de compreensão da actividade, da organização e do contencioso administrativos. Coimbra: Coimbra Editora, 2009.

MOREIRA NETO, Diogo de Figueiredo. Novos institutos consensuais da ação administrativa. Revista de direito administrativo. Rio de Janeiro: Fundação Getúlio Vargas, $\mathbf{n}^{\mathbf{0}}$ 231, jan./mar. 2003, p. 146-157.

OLIVEIRA, Carlos Alberto Álvaro de. O formalismo-valorativo no confronto com o formalismo excessivo. In: DIDIER JR., Fredie (org.). Leituras complementares de processo civil. Salvador: Jus Podivm, $7^{\text {a }}$ ed., 2009, p.59-88.

PEDROSO, João. Percurso(s) da(s) reforma(s) da administração da justiça: uma nova relação entre o judicial e o não judicial. Revista direito e democracia, vol. 4, no 1, $1^{\circ}$ sem. 2003, p.47-89. Disponível em: www.periodicos.ulbra.br/index.php/direito/article/download/2446/ 1672. Acesso em: 19.11.2017.

PEDROSO, João; TRINCÃO, Catarina; DIAS, João Paulo. Percursos da informalização e da desjudicialização por caminhos da reforma da administração da justiça (análise comparativa) - Relatório do Observatório Permanente da Justiça Portuguesa. Coimbra, Centro de Estudos Sociais, 2001. 
PORTUGAL. Ministério da Justiça. Portaria $\mathrm{n}^{\circ}$ 279, de 26 de agosto de 2013. Disponível em: https://dre.pt/pesquisa/-/search/499518/details/maximized. Acesso em: 02.02.2018.

PORTUGAL. Ministério da Justiça. Portaria n ${ }^{\circ}$ 282, de 29 de agosto de 2013. Disponível em: https://dre.pt/web/guest/pesquisa/-/search/499505/details/normal?q=Portaria+282\%2F2013+.

Acesso em: 02.02.2018.

RIBEIRO, Antônio de Pádua. Controle da atividade judiciária. Revista de informacão legislativa. Brasília: Senado Federal, v. 28, n 111, jul./set. 1991, p. 335-346.

RIBEIRO, Flávia Pereira. Desjudicialização da execução civil. São Paulo: Saraiva, 2013.

ROSA, Alexandre Morais da. A lógica da Reforma do Poder Judiciário. Jornal Carta Forense. São Paulo, out. 2012, on-line. Disponível em: http://www.cartaforense.com.br/conteudo/artigos/alogica-da-reforma-do-poder-judiciario/9502. Acesso em: 19.11.2017.

SOUSA, Miguel Teixeira de. Um novo processo civil português: à la recherche du temps perdu? RePro - Revista de processo. São Paulo: Revista dos Tribunais, v. 33, nº 161, jul. 2008, p. 203220. 